\title{
THE EFFECT OF HAY CONSERVATION ON SHEEP PRODUCTIVITY ON AN IRRIGATED ALL-GRASS FARM
}

\author{
J. M. HAYMAN* and J. H. BAIRD
}

Winchmore Irrigation Research Station, MAF, Ashburton

\section{Abstract}

Hay conservation failed to improve the productivity of sheep rotationally grazed at 20 ewes/ha on irrigated all-grass farmlets in Canterbury. There was a tendency (not statistically significant) for sheep on "no hay" farmlets to be heavier at mating and to wean heavier lambs. Some implications of grassland farming without hay are discussed.

\section{INTRODUCTION}

At stocking rates of about 20 ewes/ha on irrigated pasture in Canterbury there is often no pasture surplus for conservation. In this situation hay-making is possible only if ewe or lamb intake is restricted. Also, with the adoption of rotational grass wintering the requirement for hay in winter is greatly reduced (Hayman, 1978).

Two farmlet trials were run at Winchmore Irrigation Research Station in mid-Canterbury to measure the effect of hay conservation on the productivity of sheep stocked at 20 ewes/ha on an irrigated all-grass farm where year-round rotational grazing was practised.

\section{METHODS}

Trial A ran from August 1975 to March 1978, production measurements being recorded between March 1976 and February 1978 inclusive. The two farmlets, "no hay" and "hay" (1.4 ha each) were each stocked with mixed-age Romney ewes at 20/ha mated to Southdown rams. The ewes were randomly assigned to treatments within age and weight groups.

*Present address: Templeton Research Station, MAF, Templeton. 
Five-year-alds were culled each February and replaced by bought-in two-tooths. Deaths were replaced immediately by ewes of similar age, to maintain the stocking rate, but records were taken only from those ewes which remained on the trial for a full season, March to February inclusive.

Trial $B$ was larger ( 2.4 ha each) but of the same design as Trial A, and ran from September 1978 to February 1980 inclusive, with production measurements being recorded from March 1979 to February 1980. Five-year-old ewes were not included in the initial flock in August 1978 so that culling for age was not required in 1979. Records were taken from sheep which remained on the trial for the whole 18 months.

The five- to ten-year-old pastures used for both trials contained perennial ryegrass (Lolium perenne L.), white clover (Trifolium repens L.) browntop (Agrostis tenuis Sibth.) Bromus mollis and flat weeds.

There were 8 pairs of paddocks in Trial A and 12 in Trial B. One of each pair was randomly assigned to each treatment, with further temporary subdivisions in winter.

\section{RESULTS}

The effects of hay conservation (Table 1) on sheep productivity (Table 2), were small and not statistically significant. However, ewe mating weights and lamb weaning weights were always

TABLE 1: HAY CONSERVATION (kg DM)

\begin{tabular}{|c|c|c|c|c|c|c|}
\hline Trial & Y ear & $\begin{array}{l}\% \text { Farmlet } \\
\text { Closed }\end{array}$ & $\begin{array}{l}\text { Date } \\
\text { Closed }\end{array}$ & $\begin{array}{l}\text { Date } \\
\text { cut }\end{array}$ & $\begin{array}{c}\text { Hay } \\
\mathrm{kg} D M\end{array}$ & $\begin{array}{l}\text { Baled } \\
\mathrm{kg} / \mathrm{E} \text { we }\end{array}$ \\
\hline A & $1976-7$ & $28 \%$ & ${ }^{2} 8 \mathrm{D}_{\mathrm{ect}}^{\mathrm{ct}}$ & 24 Peaff & 1050 & 55 \\
\hline A & $1977-8$ & $28 \%$ & 20 Oct & $5 \mathrm{Dec}$ & 1200 & 38 \\
\hline B & $1978-9$ & $\begin{array}{l}17 \% \\
17 \%\end{array}$ & $\begin{array}{r}3 \text { Nov } \\
28 \text { Dec }\end{array}$ & $\begin{array}{c}5 \mathrm{Jan} \\
20 \mathrm{Mar}\end{array}$ & $\begin{array}{r}1200 \\
900\end{array}$ & 44 \\
\hline
\end{tabular}

TABLE 2: EFFECT OF HAY CONSERVATION ON SHEEP PRODUCTIVITY

(Difference of "no hay" - "hay")

\begin{tabular}{lcccc}
\hline & $1976-77$ & $\mathbf{1 9 7 7 - 8}$ & $\mathbf{1 9 7 9 - 8 0}$ & Mean Diff. \\
\hline Ewe mating wt (kg) & 1.6 & 1.4 & 2.7 & 1.9 n.s. \\
Lamb weaning wt (kg) & 0.7 & 2.6 & 2.2 & 1.8 n.s. \\
Fleece wt (kg) & -0.01 & -0.43 & -0.06 & -0.16 n.s. \\
Weaning \% LW/EJ & 0.23 & -0.09 & 0.03 & 0.06 n.s. \\
\hline
\end{tabular}


HAY CONSERVATION

TABLE 3: EWE LIVEWEIGHT CHANGE IN WINTER AND ESTIMATED PASTURE AND HAY ALLOWANCE

\begin{tabular}{|c|c|c|c|c|c|}
\hline & \multirow{2}{*}{$\begin{array}{l}\text { Ewe } \\
\text { Post- } \\
\text { mating }\end{array}$} & \multirow{2}{*}{$\begin{array}{c}\text { Liveweight } \\
\text { Pre- } \\
\text { lambing }\end{array}$} & \multirow{2}{*}{$\begin{array}{l}(\mathrm{kg}) \\
\text { Change }\end{array}$} & \multicolumn{2}{|c|}{$\begin{array}{c}\text { Allowances } \\
(k g D M / e w e / \text { day })\end{array}$} \\
\hline & & & & Pasture & Hay \\
\hline $\begin{array}{l}1976 \\
\text { No hay } \\
\text { Hay }\end{array}$ & $\begin{array}{l}61.1 \\
60.0\end{array}$ & $\begin{array}{l}63.1 \\
64.1\end{array}$ & $\begin{array}{l}2.0 \\
4.1\end{array}$ & - & - \\
\hline $\begin{array}{l}1977 \\
\text { No hay } \\
\text { Hay }\end{array}$ & $\begin{array}{l}62.6 \\
60.3\end{array}$ & $\begin{array}{l}58.8 \\
62.0\end{array}$ & $\begin{array}{r}-3.8 \\
1.7\end{array}$ & $\begin{array}{l}0.7 \\
0.7\end{array}$ & $\begin{array}{r}0 \\
0.3\end{array}$ \\
\hline $\begin{array}{l}1979 \\
\text { No hay } \\
\text { Hay }\end{array}$ & $\begin{array}{l}56.9 \\
52.6\end{array}$ & $\begin{array}{l}59.2 \\
57.3\end{array}$ & $\begin{array}{l}2.3 \\
4.7\end{array}$ & $\begin{array}{l}0.8 \\
0.5\end{array}$ & $\begin{array}{r}0 \\
0.5\end{array}$ \\
\hline
\end{tabular}

higher on the "no hay" treatment, while the small differences in fleece weight favoured the "hay" treatment.

Ewe liveweight changes, pasture and hay allowance over winter are presented in Table 3. The ewes fed hay tended to have a higher total allowance and to gain more weight.

\section{DISCUSSION}

This trial demonstrated that ewes can be wintered on irrigated grass at 20/ha without hay supplement and without any detrimental effect on their productivity.

This "no hay" system has been used with equal success for two winters on a demonstration farmlet stocked at 22.2 Coopworth ewes/ha (243 ewes) at Winchmore. A few farmers in Canterbury have also gone through one or more winters without hay, and many have greatly reduced their use of hay by adopting the rotational grass wintering system of management.

Hay has become too expensive to be used unnecessarily. However, it would be unwise to attempt to winter a large flock without an emergency feed reserve for use in times of snow, flood or other contingency. Hay for emergencies can be saved in the years of abnormally good pasture growth such as 1979-80. When there is a real surplus over stock needs, failure to make hay (or remove the surplus in some other way) will result in poor quality feed and possibly reduced pasture production. One of the problems associated with "no hay" pasture management is the maintenance of high pasture quality for lamb growth. It is essential that ewes be used for pasture control in the late spring and summer. If ro- 
tational grazing is practised throughout the year, surpluses are easily recognized and dealt with by making hay or silage for the emergency reserve, or for sale.

\section{CONCLUSIONS}

Good pasture management can eliminate the need for making large amounts of hay on irrigated all-grass farms. Hay should be regarded as an emergency feed rather than a supplement.

\section{REFERENCE}

Hayman, J. M., 1978. Proc. Irrig. Conf., Ashburton: 199-209. 